\title{
How Are The Physics Critical Thinking Skills of The Students Taught by Using Inquiry-Discovery Through Empirical and Theorethical Overview?
}

\author{
Wartono Wartono ${ }^{1}$, Muhammad Nur Hudha ${ }^{2}$, John Rafafy Batlolona ${ }^{\text {1* }}$ \\ ${ }^{1}$ State University of Malang, INDONESIA \\ 2 Universitas Kanjuruhan Malang, INDONESIA
}

Received 24 April 2017 • Revised 31 August 2017 • Accepted 1 October 2017

\begin{abstract}
Previous research reports mention several learning models which are potential in improving students' thinking skills. This quasi-experimental research aims to determine the difference in critical thinking skills of the students who learned by using inquirydiscovery model and conventional learning model in class X. The treatment of this research was teaching physics by inquiry-discovery model and conventional learning model. The instruments of critical thinking skills were developed by the researcher and validated by an expert prior to use. The results of the research showed that there was a significant difference in the critical thinking skills between the experimental class and the control class. The result of critical thinking skills of the students in the inquiry discovery class was higher than that of the conventional learning class. The research recommends that teachers empower HOTS ability of the students in the inquirydiscovery class, so that a meaningful learning and student-centered learning can be created. Future researches are needed to explore the contribution of inquiry-discovery model on students' critical thinking skills.
\end{abstract}

Keywords: critical thinking skill, inquiry-discovery, conventional, empirical and theorethical

\section{INTRODUCTION}

A number of learning skills need to be empowered in the education of the 21st century, one of which is the critical thinking skill, which is included as high-order thinking skills (Ikuonobe, 2001). These skills need to be instilled in every student to response to the extremely complex challenges (Halpern, 2003), along with the advance of science and technology which are changing the structure of society (Gumus et al, 2013). Critical thinking skill is a superior ability which plays an important role in all aspects of human life (Abed et al, 2015), problem solving (Hendricson et al, 2006; Carter et al, 2016) and decision making (Ku, 2009).

Critical thinking skills are necessary to be continuously applied in the learning process (Kealey et al, 2005). The emphasis is on the gold generation who continues their future life at the primary school to the university level. The purpose is to produce competent and skilled learners in solving problems in everyday life. The research results by Chartrand (2010) showed that 70\% of senior high school graduates lacked the competence both involving the critical thinking skills and for 4 years college students only had $28 \%$ of critical thinking skills. The factors that cause the students' critical thinking skills are less empowered are that teachers do not have a good competence in designing learning (Aybek, 2007).

Teachers, who are the main pillars of education, need to make changes in the learning system. The empowerment of the students' critical thinking skills can be done in small groups and individuals in the learning activities in class (Aktas \& Unlu, 2013). In relation to it, teachers have to design learning programs properly and engage students in each learning activity. Critical thinking skill can also be empowered by the teachers providing questions or problems that challenge students' thinking. Thus, the students' thinking structures will be more

(C) Authors. Terms and conditions of Creative Commons Attribution 4.0 International (CC BY 4.0) apply. 


\section{Contribution of this paper to the literature}

- Various high skill levels are often used by students in everyday life that can be utilized in improving the quality of learning through teacher creativity, such as students' critical thinking skill.

- Inquiry-discovery learning model through empirical and theoretical reviews can improve students' cognitive achievement on static fluid materials, which can empower students to solve real problems in everyday life and minimize student misunderstanding.

- Inquiry-discovery learning model through empirical and theoretical reviews is one of the most effective models for promoting problem-solving, reasoning, motivation and reducing student misconceptions that impact on improving the achievement of cognitive learning outcomes.

complex (Foster, 2009). The research by Whiley et al (2017) on the new students of environmental management in Queensland University found that before the students attended the lecture, they were given matriculation for a year relating to their critical thinking skills. This is because the student must be able to critically evaluate something in the workplace and society. The study can be applied in Indonesia, depending on the school principals and teachers who make the decisions in the learning process.

Another way to improve the students critical thinking skills is by using the appropriate learning model. The use of learning models can affect learning and determine the final results of the increase in the students' critical thinking skills (Mabruroh \& Suhandi, 2017). In relation to it, the learning model which is able to increase the students' critical thinking skills is inquiry-discovery (Hwang \& Chang, 2011; Duran \& Dokme, 2016), in which the students are actively involved in obtaining and discovering concepts or principles to empower their knowledge (Richardson \& Renner, 1970). Inquiry-discovery learning model not only serves to guide students in understanding concepts but also familiarizes the students in completing tasks. The concepts found during the learning process are expected to reduce the physics missunderstanding of the students.

Various researches have reported the use of inquiry- discovery learning model without using students' critical thinking skills such as addressing misconceptions of junior high school students on the topic of wave and optical (Tompo et al, 2016), students' misconceptions on the moon phase (Radzi et al, 2017), academic achievement and retention (Balim 2009). Inquiry-discovery is the combination between discovery and inquiry learning. Discovery is the process of knowledge in which the students can assimilate concepts or principles. The knowledge process is observing, categorizing, making hypothesis, explaining, measuring, drawing conclusions and so on (Alfieri et al, 2011). Inquiry is an extension of discovery that is used more in-depth. It means that the process of inquiry consists of higher order knowledge, such as resuming an issue, designing investigations, conducting investigations, collecting data, analyzing data and drawing conclusions (Apedoe et al, 2006).

Inquiry-discovery learning model allows students to use their whole knowlege (cognitive, affective and pshycomotor), especially the process of learning to find concepts or principles by themselves and trains their mental processes which is the characteristics of a scientist (Pedaste et al, 2015) and to train the students' problem solving skills (Onyancha et al, 2006). In the context of inquiry -discovery, students are given incomplete information by the teacher with the aim of encouraging them to make deductions and conclusion. In problem solving, students are directly involved in activities and individual and group discussion, with the help of teachers, students identify preconceptions. From their initial understanding, students move forward in building new knowledge with studentcentered knowledge and encourage and stimulate students' minds because they need to use their reasoning skills to solve the problems posed by the teachers and then make conclusions (Radzi et al, 2017). Thus, this research aims at revealing the potential of inquiry-discovery in empowering the students' physics critical thinking skills.

\section{METHOD}

\section{Research Type}

This research is a quasi-experimental research that aims to uncover inquiry-discovery through empirical and theoretical review in empowering students physics critical thinking skills. Inquiry-discovery and conventional learning model were the independent variables, while the critical thinking skills were the dependent variable.

\section{Population and Sample}

Thep opulation in this research was the students of class X Science. The samples in this research were 67 students who were randomly selected. The sample of this research focused on 1 senior high school in Malang with a medium level school status. This research used two classes as the experimental class $(n=34)$ and the control class $(n=33)$. The students in the experimental class were taught by using inquiry-discovery learning model, while the students 
Table 1. Score of Students' Critical Thinking Skills

\begin{tabular}{|c|c|c|c|c|}
\hline \multirow{2}{*}{ Class } & \multirow{2}{*}{ Sample } & \multicolumn{2}{|c|}{ Critical Thinking Skills } & \multirow{2}{*}{ Average Score } \\
\hline & & High & Low & \\
\hline Experiment & 34 & 85 & 55 & 72.94 \\
\hline Control & 33 & 75 & 55 & 65.45 \\
\hline
\end{tabular}

Table 2. The Critical Thinking Skill score of high academic ability Students

\begin{tabular}{|c|c|c|c|c|}
\hline \multirow{2}{*}{ Class } & \multirow{2}{*}{ Sample } & \multicolumn{2}{|c|}{ Critical Thinking Skills } & \multirow{2}{*}{ Average Score } \\
\hline & & High & Low & \\
\hline Experiment & 10 & 85 & 75 & 80.90 \\
\hline Control & 10 & 75 & 70 & 73.18 \\
\hline
\end{tabular}

Table 3. Score of the Critical Thinking Skills of the lower academic ability students

\begin{tabular}{|c|c|c|c|c|}
\hline \multirow{2}{*}{ Class } & \multirow{2}{*}{ Sample } & \multicolumn{2}{|c|}{ Critical Thinking Skills } & \multirow{2}{*}{ Average Score } \\
\hline & & High & Low & \\
\hline Experiment & 10 & 70 & 55 & 65.00 \\
\hline Control & 10 & 60 & 55 & 5727 \\
\hline
\end{tabular}

in the control class were taught by using conventional learning model. The phycics class met for two hours per week for all students. The topic learned was about static fluid.

\section{Data Collection}

The data of the critical thinking skills were collected 2 times, in the form of pretest and posttest. The pretest was carried out before the treatment was given, while the posttest was carried out after the entire treatment was given. The treatment in this research was the use of learning models, namely inquiry-discovery on the experimental class and conventional learning on the control class. The physics learning, especially on the static fluid material, was conducted for 4 meetings. The learning activities have been ensured to follow the syntax of each learning model specified, to guarantee the consistency of the inquiry-discovery learning.

\section{Research Instruments}

The instrument used in this research was critical thinking skill test as many as 12 test items. The instrument was developed by the researcher, and it was validated by learning experts and theoretical physics experts from the State University of Malang and Kanjuruhan University. The instrument was developed by refering to the 5 indicators of critical thinking skills, namely the smoothness in giving simple explanation (elementary clarification), developing basic skills (basic support), drawing conclusion (inference), giving further explanation (advanced clarification), and setting strategies and tactics (strategies and tactics) (Ennis, 1993). The critical thinking skill instrument had been empirically tested, in order to obtain information regarding the validity and reliability, which was 0.70 and 0.91 respectively.

\section{Data Analysis}

The instrument used in this research was critical thinking skill test in the form of an essay test. The critical thinking skill test covered 5 aspects. The data were analyzed by using by independent sample t-test to reveal a difference in the critical thinking skills of the students in the experimental class and in the control class. The data analysis were assisted with SPSS version 16 for Windows. Before the data were analyzed, the prerequisite tests, the normality and homogeneity, were performed. The results of the prerequisite tests indicated that the distribution of data in the control and experimental groups was normal and homogeneous.

\section{FINDINGS}

The description of the research results related to the main score of students' critical thinking skills, the critical thinking skill scores of higher and lower academic ability is presented in Tables 1, 2, and 3. Table 1 shows that in the experimental class, the highest score of critical thinking skill was 85, and the lowest score was 55 with a mean score of 72.94. In the control class, the highest score was 75, and the lowest score was 55 with the mean score of 65.45 .

Table 2 shows the critical thinking skill of the higher academic ability students. In the experimental class, the highest score was 85 and the lowest score was 75 and the average score was 80,90. In the control class, the highest score was 75 and the lowest score was 70 and the average score was 73.18. 
Table 4. The Normality test of the Students' Critical Thinking Skills

\begin{tabular}{l} 
Class \\
\cline { 2 - 7 } Critical Thinking
\end{tabular}

Table 5. Homogeneity of the Critical Thinking Skills

\begin{tabular}{ccccc}
\hline \multicolumn{5}{c}{ Levene's Test of Equality of Error Variance } \\
\hline
\end{tabular}

Table 3 shows the critical thinking skills of the lower academic ability students. In the experimental class, the highest score was 70 and the lowest score was 55 with the average score of 65.00 . In the control class, the highest score was 60, the lowest score was 55, and the average score was 57.27.

The normality test was carried out using statistical Kolmogorov-Smirnov and Shapiro-Wilk at a significance level of 5\% with SPSS 16.0 for windows. The results of normality test of the critical thinking skills are presented in Table 4.

Table 4 on the results of normality test using the Kolmogorov-Smirnov test showed that the significance value was greater than 0.05 . Thus, the data of students' critical thinking skills are normally distributed, so that it could be proceeded to hypothesis testing.

\section{Testing of Homogeneity}

The homogeniety of this research was tested using Levene's Test of Equality of Error Variances to test of homogeneity variance, the first significance 5\% with SPSS 16.0 for windows. As for the result of the test of homogeneity of variance-covariance critical thinking, presented in Table 5.

In Table 5 test results of homogeneity variance from the data test critical thinking show significance were greater than 0.05 . Thus can be concluded that data test level think critical thinking come from the homogeneous.

\section{Testing of Hypotheses}

The testing of hypotheses in this research using the analysis Anova in the level of significance of 5\% with SPSS 16.0 assistance program for windows. Hypothesis in this research was "critical thinking skills students learned by learning inquiry-discovery through empirical and theoretical, review higher than students who learn physics to conventional learning. The testing of hypotheses the research was done in order to provide of statistically, do hypothesis advanced by in this research may be accepted or rejected.The results of the analysis ANOVA.

Hypothesis tested by analyzing couples hypothesis zero of $\left(h_{0)}\right.$ and hypotheses comparison $\left(h_{1)}\right.$ as follows.

$\mathbf{H}_{0}=$ no the difference in the think critically, between students learned by learning discovery through empirical and theoretical review with students of learned by conventional learning.

$\mathbf{H}_{\mathbf{1}}=$ level think critically, students who studied to learning discovery through empirical review and theoretical higher than students learned by conventional learning.

Pillai's Trace, Wilks' Lambda, Hotelling's Trace, and Roys's Largest Root on effect of learning all shows a figure significance (sig.) $=0.000<0.05$ and at Table 6 which show source of learning is against the dependent variable for the level of think critically Obtained $F=18.354$ with significance (sig.) $=0.000<0.05$. Thus Spake $\mathrm{h}_{0}$ rejected and $\mathrm{H}_{1}$ accepted, this means shows that the critical thinking who Learns by learning inqury-discovery through empirical and theoretical review, higher than students who learn by learning conventional seen from the average level of think critically students who learn by discovery learning through is 68.76 while students who Learns by conventional learning is 65.58 . 
Table 6. Pillai's Trace, Wilks' Lambda, Hotelling's Trace, dan Roys's Largest Root on effect of Learning

\begin{tabular}{ccccccc}
\hline & Effect & Value & $\mathbf{F}$ & Hypothesis df & Error df & Sig. \\
\hline \multirow{4}{*}{ Intercept } & Pillai's Trace & .995 & $6.016 \mathrm{E3}^{\mathrm{a}}$ & 2.000 & 64.000 & .000 \\
\cline { 2 - 7 } & Wilks' Lambda & .005 & $6.016 \mathrm{E3}^{\mathrm{a}}$ & 2.000 & 64.000 & .000 \\
\cline { 2 - 7 } & Hotelling's Trace & 187.995 & $6.016 \mathrm{E3}^{\mathrm{a}}$ & 2.000 & 64.000 & .000 \\
\hline & Roy's Largest Root & 187.995 & $6.016 \mathrm{E} 3^{\mathrm{a}}$ & 2.000 & 64.000 & .000 \\
\hline \multirow{3}{*}{ Learning } & Pillai's Trace & .243 & $10.275^{\mathrm{a}}$ & 2.000 & 64.000 & .000 \\
\cline { 2 - 7 } & Wilks' Lambda & .757 & $10.275^{\mathrm{a}}$ & 2.000 & 64.000 & .000 \\
\cline { 2 - 7 } & Hotelling's Trace & .321 & $10.275^{\mathrm{a}}$ & 2.000 & 64.000 & .000 \\
\cline { 2 - 7 } & Roy's Largest Root & .321 & $10.275^{\mathrm{a}}$ & 2.000 & 64.000 & .000 \\
\hline
\end{tabular}

${ }^{*} p<0.05,{ }^{* *}<0.001$

\section{DISCUSSION}

The results of the research indicate that the critical thinking skills of the students taught by using inquiry discovery model through empirical and theoretical study are higher than those of the students taught by using conventional learning. The students taught by using inquiry-discovery learning participated more actively in learning. This is because the students were given the opportunity to find their own knowledge to be conveyed through direct experiments. Sweller et al (2007) states that high academic ability students are able to follow the learning well, compared to the low academic ability students. Therefore, the inquiry - discovery learning can improve the ability of the low academic ability students (Alex \& Olubusuyi, 2013). Inquiry - discovery learning facilitates students to learn through active involvement, and teachers encourage students to have the experience and conduct experiments that enable them to discover concepts or principles without requiring the help of a teacher (Saab et al, 2005).

A teacher must try to use guided discovery approach to engage students in problem-solving activities (Onyancha et al, 2006), independent learning, critical thinking and understanding, and creative learning. An important thing in discovery learning is that students are given the opportunity to do experiments, so that their curiosity grows better when doing experiments, then they find hypotheses and have discussion of the results of experiments conducted. Based on the advantages that have been explained, the inquiry-discovery learning through empirical and theoretical reviews provide better results in the achievement of the students' critical thinking skill than the students taught by using conventional learning.

The average difference in the students' achievement is due to the different treatment between the experimental class and the control class. Inquiry - discovery is a learning model which is based on discovery and experience as on the static fluid material about Archimedes law. In the learning, the students conduct an experiment to know the Archimedes law through the practical work they are doing, so that they can easily remember the Archimedes law. Students understand the concepts of Archimedes easily based on their practicum experience. Thus, the achievement of the students who learned by using discovery learning is better than those who learned by using conventional learning.

When conducting an experiment in the experimental class, the students were more active and enthusiastic in following the learning activities, and the students' curiosity was higher. The students were very active and happy as they could find the Archimedes law by themselves through experiments. According to Makoolati et al, (2015) discovery learning provides opportunities for student-centered activities and allows students to learn from not only teachers as the only source of learning.

The advantages that the students get from this learning model are that it can trigger the students curionsity and independent learning in problem solving. Therefore, in this research, the students who learned by using inquiry discovery through empirical and theoretical reviews had higher critical thinking skills than those who learned by using conventional learning. As already known, physics is a science learning category that requires experimental activities to understand the concepts or principles. In addition to increasing critical thinking skill, it also increases students' learning achievement, because the students independently learn to get the results of the experiment which they do to prove a theory. This process can help students develop their knowledge because the conduct the experiment by themselves which is later perfected by the teacher's explanation. In such learning, the teacher is not the main icon of learning, but the students are. Thus, the students have a big opportunity to construct their critical thinking. 


\section{CONCLUSION}

Inquiry - discovery learning through empirical and theoretical review generates higher critical thinking skills than the conventional learning does. Therefore, the inquiry - discovery learning is recommended for the learning of other physics materials to improve the students' critical thinking skills. Future researches are expected to do comprehensive overview on the other high order thinking skills.

\section{REFERENCES}

Abed, S., Davoudi, A. M. H., \& Hoseinzadeh, D. (2015). The effect of synectics pattern on increasing the level of problem solving and critical thinking skills in students of alborz province. WALIA Journal, 31(1), 110-118.

Aktas, G. S., \& Unlu, M. (2013). Critical thinking skills of teacher candidates of elementary mathematics, ProcediaSocial and Behavioral Sciences, 93, 831-835.

Alex, A. M., \& Olubusuyi, M. F (2013). Guided-discovery learning strategy and senior school students performance in mathematics in ejigbo, nigeria. Journal of Education and Practice, 4(2), 82-89.

Alfieri, L., Brooks, P. J., Aldrich, N. J., \& Tenenbaum, H. R. (2011). Does discovery-based instruction enhance learning? Journal of Educational Psychology, 103(1), 1-18.

Apedoe, X. S., Walker, S. E., \& Reeves, T. C. (2006). Integrating inquiry-based learning into undergraduate geology, Journal of Geoscience Education, 54(3), 414-421.

Aybek, B. (2007). Eleştirel Düşünmenin Öğretiminde Öğretmenin Rolü. Bilim, Eğitim ve Düşünce Dergisi, 7(2). http://www.universitetoplum.org.

Balim, A. G. (2009). The effects of discovery learning on students' success and inquiry learning skills. Eurasian Journal of Educational Research, 35, 1-2.

Bernard, R. M., Zhang, D., Abrami, P. C., Sicoly, F., Borokhovski, E., \& Surkes, M. A. (2008). Exploring the structure of the watson-glaser critical thinking appraisal: one scale or many subscales?. Thinking Skills and Creativity, $3(1), 15-22$.

Carter, A. G., Creedy, D. K., \& Sidebotham, M. (2016). Efficacy of teaching methods used to develop critical thinking in nursing and midwifery undergraduate students: a systematic review of the literature. Nurse Education Today, 40, 209-218.

Chartrand, J. (2010). My thinking styles: Development report [Measurement instrument]. San Antonio, TX: Pearson Education. Retrieved from http:/ / www.thinkwatson.com/mythinkingstyles

Duran, M., \& Dokme, I. (2016). The effect of the inquiry-based learning approach on student's critical-thinking skills. Eurasia Journal of Mathematics, Science E Technology Education, 12(12), 2887-2908.

Ennis, R. H. (1993). Critical Thinking Assessment. Theory into Practice, 32(3), 179-86.

Foster, J. (2009). Thinking Skills in: B. Kerr (Ed.) Encyclopedia of giftedness, Creativity, and talent (pp. 898- 899). California: SAGE.

Gumus, S. S., Gelen, S., \& Keskin, A. (2013). Value acquisition, critical thinking skills and the performance of 6 th grade students. Education, 41(3), 254-264.

Halpern, D. (2003). Thought and knowledge: An introduction to critical thinking. (4th Ed.). Mahwah, NJ: Lawrence Erlbaum Associates.

Hendricson, W. D., Andrieu, S. C., \& Chadwick, G. (2006). Educational strategies associated with development of problem-solving, critical thinking, and self-directed learning. Journal of Dental Education, 70, 925-936.

Hwang, G. J., \& Chang, H. F. (2011). A formative assessment-based mobile learning approach to improving the learning attitudes and achievements of students. Computers $\mathcal{E}$ Education, 56, 1023-1031.

Ikuonobe, P. (2001). Teaching and assessing critical thinking abilities as outcomes in an informal logic course. Teaching In Higher Education, 6(1), 19-32.

Kealey, B. T., Holland, J., \& Watson, M. (2005). Preliminary evidence on the association between critical thinking and performance in principles of accounting. Issues in Accounting Education, 20(1), 33-49.

Ku, K. Y. L. (2009). Assessing students' critical thinking performance: Urging for measurements using multiresponse format. Thinking Skills and Creativity, 4(1), 70-76.

Mabruroh, F., \& Suhandi, A. (2017). Construction of critical thinking skills test instrument related the concept on sound wave. IOP Conf. Series: Journal of Physics: Conf. Series, 812 (012056), 1-7.

Makoolati, N., Amini, M., Raisi, H., Yazdani, Sh., \& Razeghi, A. V. (2015). The effectiveness of Guided Discovery Learning on the learning and satisfaction of nursing students, Hormozgan Medical Journal, 18(6), 490-496. 
Onyancha, R., Armour, K., \& Endrizzi, M. (2006). Teaching inquiry and the impact of performance based assessments. In Proceedings of the ASEE New England Section 2006 Annual Conference. New England.

Pedaste, M., Maeots, M., Siiman, L. A., Jong T, d., van Riesen, S. A. N., Kamp, E. T., Manoli, C. C., Zacharia, Z. C., \& Tsourlidaki, E. (2015). Phases of inquiry-based learning: Definitions and the inquiry cycle. Educational Research Review, 14, 47-61.

Radzi, R. M., Abdullah, M. N. S., \& Muruthi, K. (2017). Inquiry-discovery teaching approach as a means to remediate primary students' misconception about the phases of the moon. Overcoming Students' Misconception in Science, 71-87.

Richardson, V., \& Renner, J. W. (1970). A study of the inquiry-discovery method of laboratory instruction, Journal of Chemical Education, 47(1), 77-79.

Saab, N., van Joolingen, W. R., \& van Hout-Wolters, B. H. A. M. (2005). Communication in collaborative discovery learning. British Journal of Educational Psychology, 75, 603-621.

Sund, R. B., \& Trowbridge, L. W. (1973). Teaching Science by Inquiry in the Secondary School. Columbus Ohio, Charles E. Merril Publishing Company.

Sweller, J. (2009). What human cognitive architecture tells us about constructivism? In S. Tobias \& T. M. Duffy (Eds.), Constructivist theory applied to instruction: Success or failure? (pp. 127-143). New York, NY: Taylor \& Francis.

Tompoa, B., Ahmada, A., \& Murisa, M. (2016). The development of discovery-inquiry learning model to reduce the science misconceptions of junior high school students, International Journal of Environmental $\mathcal{E}$ Science Education, 11(12), 5676-5686.

Whiley, D., Witta, B., Colvina, R. M., Arruea, R. R., \& Kotira, J. (2017). Enhancing critical thinking skills in first year environmental management students: a tale of curriculum design, application and reflection, Journal of Geography in Higher Education, 41(2), 1-16.

\section{http://www.ejmste.com}

